\title{
СОВРЕМЕННЫЕ РОССИЙСКИЕ ЭКОНОМИЧЕСКИЕ ШКОЛЫ: ПОДХОДЫ К КЛАССИФИКАЦИИ
}

\author{
Платонова Елена Дмитриевна \\ д.э.н., профессор \\ ФГБОУ ВО «Московский педагогический \\ государственный университет»
}

\begin{abstract}
Аннотация: Рассмотрены понятие «экономические школы» и соотношение с понятием «направление экономической мысли», выделены широкий и узкий подходы к содержанию понятия «экономические школы», определен авторский подход к классификации современных российских экономических школ, исходя из предмета их исследования.

Ключевые слова: экономические школы, направления экономической мысли, широкий и узкий подходы, классификация современных российсских экономических школ.
\end{abstract}

\section{MODERN RUSSIAN ECONOMIC SCHOOLS: CLASSIFICATION APPROACHES}

\section{Platonova Elena Dmitrievna}

\begin{abstract}
The concept of "economic schools" and the relationship with the concept of "direction of economic thought" are considered, broad and narrow approaches to the content of the concept of "economic schools" are highlighted, the author's approach to the classification of modern Russian economic schools is determined based on the subject of their research.

Key words: economic schools, directions of economic thought, broad and narrow approaches, classification of modern Russian economic schools.

В современной экономической науке как особой сфере социальногуманитарного знания, понятие «экономическая школа» не имеет однозначного определения своего содержания и признанной мировым и/или национальным экономическим сообществом классификации.
\end{abstract}


В научной и учебной литературе, как правило, авторами выделяются основные направления экономической мысли, исходя из времени их возникновения и тех основных экономических проблем, которые они решали в исторически определенную эпоху развития экономики. Анализ показывает, что практически всеми авторами выделяются следующие основные направления экономической мысли от зарождения раннекапиталистических производственных отношений до наших дней:

- меркантилизм ( У. Петти, Антуан де Монкретьен, Томас Ман и др.)

- физиократы ( Ф. Кэне, П. Буагильбер, В. Мирабо, Д. Неймур и др.)

- классическое (А. Смит, Д. Рикадро, Дж. Милль, неорикардианство и др.)

- неоклассическое (маржинализм, экономико-математическое, монетаризм, либерализм, школа рациональных ожиданий и др.)

- социал-демократическое (марксизм, ленинизм, К. Каутский, Ю. Мартов, Р. Люксембург, О. Шик и др.)

- историческое ( Ф. Лист, В. Рошер, Г. Шмолер, В. Зомбарт, М. Вебер и др.)

- кейнсианское (Д.М. Кейнс, дирижизм и др.)

- институциональное ( Т. Веблен, Д. Коммонс, У. Митчел и др.)

- нео(пост)кейнсианское (М. Калецкий, Д. Харрод, Э. Хансен, Е. Домар и др.)

- неоинституциональное (Р. Коуз, А. Алчиан, Д. Норт и др.)

современные теоретические интерпретации содержания всех экономических направлений (современные западные школы и российские экономические школы) [1].

Современная экономическая школа - это более узкое по объему понятие по сравнению с понятием «направление экономической мысли» и оно отражает:

- общность предмета исследования (например - институты, специфика рыночного механизма, роль государства и др.) при признании экономики сложной системой;

- наличие коллектива экономистов-единомышленников (печатного издания, ВУЗ, НЦ);

- собственные способы доступа к предмету исследованию (методы, технологии, методики, инструменты) 
- способность к продуцированию нового знания, выделяющего данную школу среди других сообществ;

- эффект саморазвития и самообогащения, базирующегося на обмене результатами и идеями как внутри одного поколения, так и между учителями и учениками.

Современные российские экономические школы целесообразно рассматривать с позиции анализа их определения в широком и узком смысле этого понятия.

В широком смысле как определенное множество научных творческих коллективов, представленных российскими экономистами и работающих в российских научных центрах, вузах, академических институтах безотносительно разделяемых ими теоретических и методологических положений и направлений.

В узком смысле как научное сообщество современных экономистов, разделяющих идею о значительном влиянии национальных особенностей («российского грунта» - почвенники) на теоретические положения российской экономической науки и отражающих специфику российской цивилизации (наследники выдающихся ученых и политических деятелей, как М.И. Туган-Барановский, Н.Д. Кондратьев, С.Ю. Витте, Д.И. Менделеев, Н.К. Михайловский, М.М. Ковалевский, В.П. Воронцов, А.И. Васильчиков,), П.Б. Струве, Н.С. Булгаков, Д.И. Пихно и А.А. Богданов, А.И. Чупров и И.И. Янжул, Е.Е. Слуцкий и В.К. Дмитриев, С.Н. Прокопович и А.Д. Билимович, А.В. Чаянов и А.Н. Челинцев, Л.Н. Юровский и Г.А. Фельдман и др.).

Однако такой методологический прием должен быть дополнен результатами ответов на вопросы: «Как классифицировать современные российские экономические школы в широком смысле?» и «Что положить в основу, чтобы выделить содержательную концептуальную сторону данных экономических школ и отличия их теоретических позиций и выводов?».

По нашему мнению, все экономические школы имеют единый объект исследования - экономику как систему отношений, то есть системное образование, являющееся элементом системы более высокого порядка общества. Современная экономика как сложная система отношений включает внутренне взаимосвязанные группы отношений - элементы, каждый из которых составляет предмет исследования той или иной современной 
экономической школы: технико-технологические; социально-экономические; организационно-экономические; институциональные; ценностно-аксиологические; экологические.

Рассмотрим в рамках этой статьи два подхода к классификации технико-технологический и социально-экономический.

Среди современных российскиз экономических школ, выбравших в качестве предмета исследования определенный аспект эволюции и развития технико-технологических отношений можно выделить:

- Волновая школа циклических закономерностей (Н. Кондратьев, А. Акаев, Р. Гринберг, Л. Гринин и др.);

- Школа сменяемости технико-технологических укладов (академики Д. Львов, С. Глазьев и др.);

- Школа критики постиндустриализма (В. Якунин, С. Сулакшин, В. Багдасарян и др.);

- Школа новой экономики (Е. Авдокушин, А. Григорян, Н. Пашкус и др.)

- Школа инновационной экономики (В. Иноземцев, А. Спартака, Е. Ясина, Ю. Яковец и др.);

- Школа цифровой экономики (Е. Ведута, С. Ильенкова, Л. Гончаренко, В. Маевский и др.);

- Школа экономики знания (Р. Нижегородцев, В. Тамбовцев, В. Макаров и др.).

Перечисленные выше экономические школы не исчерпывают всего спектра российских экономических школ, исследующих техникотехнологические отношенияч и их влияние на развитие экономических систем национальных государств.

Современные российские экономические школы, выбравшие в качестве предмета исследования определенный аспект эволюции и развития социальноэкономических отношений, представлены:

- Школа социоэкономики (А. Бузгалин, А. Колганов и др.);

- Школа эволюционной экономики (В. Маевский, Г. Клейнер, Р. Нуреев, Н. Макашева и др.);

- Школа развития человеческого капитала (С. Валентей, С. Курганский, Я. Кузьминов, В. Щетинин и др.); 
- Школа социального партнерства (М. Баглай, Б. Генкин, Н. Курбанов, И. Маслова и др.);

- Школа распределительных отношений (М. Токсанбаева, В. Радаев, А. Разумов, Н. Римашевская и др.);

- Школа трансформации экономических систем (Г. Клейнер, В. Полтерович, Н. Петраков, Р. Евстигнеев и др.);

- Школа смешанной экономики (Л.Абалкин, Ю. Ольсевич, Ю. Яременко и др.).

В Московском педагогическом государственном университете на кафедре экономичесской теориии и менеджмента получили развитие оригинальные экономические школы. Среди них можно отметить:

- Школа экономики и финансов образования (М.M. Мусарский [2, 3] и др.);

- Школа институтов интеграции в мировой экономике (Е.Д. Платонова[4] и др.);

- Школа макроэкономического равновесия (М.О. Лихачев[5] и др.);

- Школа развития предпринимательского образования (М.М. Мусарский, О.И. Игумнов, Е.Д. Платонова [6], Авдокушин Е.Ф. [7] и др.).

Предложенный подход к классификации современных российских экономических школ отражает авторкую точку зрения и будет развит в будущих исследованиях.

\section{Список литературы}

1. Платонова Е.Д. Экономическая методология: вопросы методологии. М.: АПКиППРО. - 2016. - 160 с.

2. Мусарский М.М. Общее образование: экономические механизмы// Народное образование. - 2010. - № 10 (403). - с. 109-116.

3. Мусарский М.М. Финансовый менеджмент в общеобразовательном учреждении//Непрерывное педагогическое образование.ru. - 2012. -№ 1. - c. 35

4. Платонова Е.Д. Институты интеграции и их роль в формировании и развитии региональных межгосударственных интеграционных экономических образований/Высшая школа: научные исследования. Материалы 
Межвузовского международного конгресса (г. Москва, 19 августа 2021 г.). Москва: Издательство Инфинити. - 2021. - с.7-16.

5. Лихачев М.О. Теория макроэкономического равновесия в контексте методологических проблем современной экономической науки// Вопросы экономики. - 2008. - № 7. - с. 77-88.

6. Мусарский М.М., Игумнов О.А., Платонова Е.Д. Европейский опыт и перспективы развития предпринимательского образования в российских школах// Современная конкуренция. - 2018. - №1 . - c.62-75.

7. Авдокушин Е.Ф. Как начать свой бизнес: дух предпринимательства //Вопросы новой экономики. - 2015. - №2 (34). - c.4-14. 